\title{
Granulocyte macrophage colony-stimulating factor enhances the modulatory effect of cytokines on monocyte-derived multinucleated giant cell formation and fungicidal activity against Paracoccidioides brasiliensis
}

\author{
Magda Paula Pereira do Nascimento', Camila Ferreira Bannwart², \\ Erika Nakaira-Takahagi ${ }^{2}$, Maria Terezinha Serrão Peraçoli ${ }^{2}+$ \\ 'Departamento de Doenças Tropicais, Faculdade de Medicina ²Departamento de Microbiologia e Imunologia, \\ Instituto de Biociências, Universidade Estadual Paulista, Botucatu, SP, Brasil
}

\begin{abstract}
Multinucleated giant cells (MGC) are cells present in characteristic granulomatous inflammation induced by intracellular infectious agents or foreign materials. The present study evaluated the modulatory effect of granulocyte macrophage colony-stimulating factor (GM-CSF) in association with other cytokines such as interferon-gamma (IFN- $\gamma$ ), tumour necrosis factor-alpha, interleukin (IL)-10 or transforming growth factor beta (TGF- $\beta$ ) on the formation of MGC from human peripheral blood monocytes stimulated with Paracoccidioides brasiliensis antigen (PbAg). The generation of MGC was determined by fusion index (FI) and the fungicidal activity of these cells was evaluated after $4 \mathrm{~h}$ of MGC co-cultured with viable yeast cells of $\mathrm{P}$. brasiliensis strain 18 (Pb18). The results showed that monocytes incubated with PbAg and GM-CSF plus IFN- $\gamma$ had a significantly higher FI than in all the other cultures, while the addition of IL-10 or TGF- $\beta$, had a suppressive effect on MGC generation. Monocytes incubated with both pro and anti-inflammatory cytokines had a higher induction of foreign body-type MGC rather than Langhans-type MGC. MGC stimulated with PbAg and GM-CSF in association with the other cytokines had increased fungicidal activity and the presence of GM-CSF also partially inhibited the suppressive effects of IL-10 and TGF- $\beta_{r}$. Together, these results suggest that GM-CSF is a positive modulator of PbAg-stimulated MGC generation and on the fungicidal activity against Pb18.
\end{abstract}

Key words: Paracoccidioides brasiliensis - cytokines - multinucleated giant cells - fungicidal activity

Multinucleated giant cells (MGC) are a common feature of granulomatous lesions induced by intracellular pathogens such as fungi and mycobacterium. MGC are also formed in vitro from peripheral blood mononuclear cells (PBMC) by stimulation with cytokines and lectins (Okamoto et al. 2004, Nascimento et al. 2008). Considerable evidence suggests that MGC are formed by the fusion of cells in the mononuclear phagocyte lineage, particularly monocytes from human blood (Enelow et al. 1992a, Anderson 2000). The phenomenon of adherent macrophage fusion in both human and experimental animals is enhanced in vitro by the addition of cytokines (McInnes \& Rennick 1988, Chensue et al. 1992), specific antibodies (Orentas et al. 1992), mitogens (Hassan et al. 1989) and conditioned medium (Mizuno et al. 2001, Nascimento et al. 2008). Interferon-gamma (IFN- $\gamma$ ) is essential for MGC generation by promoting cell clustering and cell-to-cell adhesion (Most et al. 1990, Fais et al. 1994). Antibodies against IFN- $\gamma$ inhibit MGC formation both in vitro (Fais et al. 1994) and in vivo (Belosevic et al. 1989).

Financial support: FAPESP (03/13743-0)

+ Corresponding author: peracoli@ibb.unesp.br

Received 3 March 2011

Accepted 9 August 2011
MGC are generally classified morphologically; Langhans giant cells (LGC) have a small number of nuclei in a circular arrangement in the periphery of the giant cell and foreign body giant cells (FBGC) have nuclei scattered in an irregular pattern throughout the giant cell (McNally \& Anderson 1995, Anderson 2000, Mizuno et al. 2001). FBGC are characteristic in foreign body granulomas. LGC are often seen in infectious granulomatous disorders such as tuberculosis (Lockwood et al. 2008), leprosy (Puissegur et al. 2007) and paracoccidioidomycosis (De Brito \& Franco 1994). LGC are observed in immune granulomas containing epithelioid cells and macrophages with difficult to digest microorganism particles surrounded by a peripheral lymphocytic mantle that may be immune $\mathrm{T}$ cells against the irritant agent. Products released from these activated $\mathrm{T}$ cells, mainly IFN $-\gamma$ initiate the monocyte and macrophage fusions and eventual LGC formation (Anderson 2000).

Helming and Gordon (2007) proposed that MGC formation in a granuloma could be induced by the cytokines and signals derived from bacteria, parasites or other foreign materials and that this local environment induces expression of fusogenic factors; therefore, the induction or modulation of MGC formation may be enhanced or suppressed depending on the cytokines present during the initial stimulus. In addition to IFN- $\gamma$ other pro-inflammatory cytokines such as tumour necrosis factor-alpha (TNF- $\alpha$ ) and granulocyte macrophage col- 
ony-stimulating factor (GM-CSF) have been employed in the in vitro generation of MGC (Gasser \& Most 1999, Tambuyzer \& Nouwen 2005).

Paracoccidioidomycosis is caused by the dimorphic fungus Paracoccidioides brasiliensis and is the most prevalent systemic human mycosis in Latin American countries (Franco et al. 1993, Wanke \& Londero 1994). The clinical manifestations of paracoccidioidomycosis are a chronic epithelioid granulomatous disease (Montenegro \& Franco 1994) and an inflammatory response induced by the fungus that is supposed to prevent the fungus dissemination (Iabuki \& Montenegro 1979, Franco et al. 1993). In some histopathology studies of paracoccidioidomycosis in patients and experimentally infected animals, granulomatous lesions with MGC containing fungal cells were present, which suggests that MGC have a role in the fungus-killing process (Parise-Fortes et al. 2006). The specific role of MGC in inflammatory infection is not known; however, Enelow et al. (1992b) suggest that monocyte cultures stimulated with interleukin (IL)-3 and IFN- $\gamma$ generate MGC with enhanced candidacidal activity.

An in vitro model may be critical for understanding the mechanisms of lesion formation in paracoccidioidomycosis. The in vitro generation of MGC using $P$. brasiliensis antigen $(\mathrm{PbAg})$ with various pro and antiinflammatory cytokines and the ability to assess the fungicidal activity of these cells against $P$. brasiliensis strain $18(\mathrm{~Pb} 18)$ has not been previously investigated.

Thus, in this study, we evaluated the effects of GMCSF in association with IFN- $\gamma$, IL-10, transforming growth factor beta (TGF- $\beta_{1}$ ) or TNF- $\alpha$ to modulate MGC generation from $\mathrm{PbAg}$-stimulated human blood monocytes. The fungicidal activity of the generated MCG was determined by in vitro challenge with Pb18.

\section{SUBJECTS, MATERIALS AND METHODS}

Healthy individuals - Twenty healthy blood donors between 20-50 years of age (mean age $31.5 \pm 10.2$ years) were recruited from the Botucatu Medical School at São Paulo State University, Brazil. The Botucatu Medical School Ethics Committee on human research approved the study and informed consent was obtained from all the blood donors.

Fungal strain - Pb18 was maintained in the yeast form at $35^{\circ} \mathrm{C}$ in glucose-peptone-yeast (GPY) culture medium $(2 \%$ glucose, $1 \%$ peptone, $0.5 \%$ yeast extract and $2 \%$ agar) for six days. Yeast viability was determined by phase-contrast microscopy (Soares et al. 2001) and fungal suspensions containing more than $90 \%$ viable cells were used for the experiments.

Preparation of antigen - $\mathrm{PbAg}$ was prepared from $\mathrm{Pb} 18$ cultured on GPY agar at $35^{\circ} \mathrm{C}$ for five days as described previously (Nascimento et al. 2008). The fungal growth from three randomly selected tubes (about $300 \mathrm{mg}$, wet weight) was collected by gently scraping the surface. The cell mass was suspended in $1 \mathrm{~mL}$ of $0.15 \mathrm{M}$ phosphatebuffered saline (PBS), pH 7.4, mixed for $30 \mathrm{~s}$ in a Vortex mixer (Technal, São Paulo, Brazil) and immediately centrifuged at 5,000 rpm in an Eppendorf tabletop centrifuge (Sorvall MC 12 V; Dupont, Newtown, CT, USA) for
$60 \mathrm{~s}$. The resulting supernatant containing the cell-free antigen was filtered through a $0.22 \mu \mathrm{m}$ membrane (Millipore Corporation, Bedford, MA). Protein concentration was determined by the Lowry et al. (1951) method.

Water extraction of yeast phase cells - The water extract of Pb18 was prepared according to Kurita et al. (1993) with modifications. Yeast phase cells of Pb18 strain were inoculated into a liquid GPY culture medium and incubated at $35^{\circ} \mathrm{C}$ for five days in a horizontal shaker at $140 \mathrm{rpm}$ (Forma Scientific). Yeast cell growth was harvested, centrifuged at 2,500 rpm for $15 \mathrm{~min}$ and suspended in sterile distilled water at a density of $10 \%$ (v:v). The suspensions were heated at $120^{\circ} \mathrm{C}$ for $15 \mathrm{~min}$ and allowed to stand at room temperature (RT) for three days. After centrifuging at 2,500 rpm for $15 \mathrm{~min}$, supernatants were removed and aseptically stored at $-20^{\circ} \mathrm{C}$ until use.

Isolation of PBMC - Heparinised venous blood was obtained from healthy adult volunteers who had given informed consent. PBMC were isolated by density gradient centrifugation with Histopaque [density $(\mathrm{d})=1.077$ ] (Sigma Chemical Co, St Louis, MO, USA). Briefly, $5 \mathrm{~mL}$ of heparinised blood was mixed with an equal volume of Roswell Park Memorial Institute (RPMI)-1640 tissue culture medium (Gibco Laboratories, Grand Island, NY, USA) containing $2 \mathrm{mM}$ L-glutamine, $10 \%$ heat-inactivated fetal calf serum, $20 \mathrm{mM}$ HEPES and $40 \mu \mathrm{g} / \mathrm{mL}$ gentamicin [complete tissue culture medium (CTCM)]. Samples were layered over $5 \mathrm{~mL}$ Histopaque in a $15 \mathrm{~mL}$ plastic conical centrifuge tube. After centrifuging at $300 \mathrm{~g}$ for $30 \mathrm{~min}$ at RT, the interface layer of PBMC was carefully aspirated and washed twice with PBS-ethylenediamine tetraacetic acid and once with CTCM at $300 \mathrm{~g}$ for $30 \mathrm{~min}$. Cell viability was determined by $0.2 \%$ Trypan blue exclusion and was $>95 \%$ in all experiments. Monocytes were counted using neutral red $(0.02 \%)$ and the mononuclear cells were suspended at a concentration of $2 \times 106$ monocytes $/ \mathrm{mL}$ in CTCM. Monocyte preparations routinely contained $>90 \%$ monocytes, as determined by morphologic examination and staining for nonspecific esterase ( $\mathrm{Li}$ et al. 1973).

MGC formation - Monocyte suspensions $\left(2 \times 10^{6}\right.$ cells $/ \mathrm{mL}$ ) were dispensed as a $50 \mu \mathrm{L}$ droplet in the centre of a well in a 24-well flat-bottomed plate (Linbro Titertek, Flow Laboratories Inc, Mclean, VA) to produce a dense monolayer of adherent monocytes (Enelow et al. 1992a). After incubation for $2 \mathrm{~h}$ at $37^{\circ} \mathrm{C}$ under $5 \% \mathrm{CO}_{2}$, the wells were rinsed twice with RPMI and $1 \mathrm{~mL} \mathrm{CTCM}$ was added to each well. For generation of MGC, monocytes were cultured adherently in CTCM with one of the following additions: $\mathrm{PbAg}(100 \mu \mathrm{g} / \mathrm{mL}), \mathrm{PbAg}$ plus GM-CSF $(50,100,200,500$ and 1,000 IU/mL), PbAg plus IFN- $\gamma(50,100,300$ and $1,000 \mathrm{IU} / \mathrm{mL}), \mathrm{PbAg}$ plus IL-10 $(50,100$ and $200 \mathrm{IU} / \mathrm{mL}), \mathrm{PbAg}$ plus TGF- $\beta_{1}(50$, $100,250$ and $500 \mathrm{pg} / \mathrm{mL}), \mathrm{PbAg}$ plus TNF- $\alpha(50,100$ and $200 \mathrm{IU} / \mathrm{mL}$ ) or PbAg and GM-CSF with the other cytokines (IFN- $\gamma$, IL-10, TGF- $\beta_{1}$ or TNF- $\alpha$ ). All the recombinant cytokines were purchased from R \& D Systems (Minneapolis, MN, USA). The optimal concentration of these cytokines was standardised and utilised in the MGC formation assay. Cells were checked for clustering 
and fusion after three days of culture using an inverted microscope (Nikon, Tokyo, Japan). At this time the culture medium was removed from the well, cells were fixed and stained with May-Grunwald-Giemsa (Sigma).

Determination of the fusion index (FI) - The fusion rate of monocytes was determined by counting the number of stained nuclei within MGC (defined as cells with 3 or more nuclei per cell) and the total number of nuclei within a given field under a microscope at 200X magnification (Nascimento et al. 2008). The FI was calculated according to the following formula: FI $(\%)=$ (number of nuclei within MGC/total number of nuclei counted) $\mathrm{x}$ 100. In each experiment, between 300-500 nuclei were counted from selected representative fields.

Fungicidal activity of MGC challenged with Pb18 Monocyte cultures for MGC generation were cultured for $72 \mathrm{~h}$ with $\mathrm{PbAg}$ and the different cytokines as described above. Supernatants were then removed and the cultures were challenged with $4 \times 10^{4}$ viable $\mathrm{Pb} 18$ yeast cells. After $4 \mathrm{~h}$ of co-culture (experimental cultures), MGC and $\mathrm{Pb} 18$ cells were harvested by aspiration with sterile distilled water to lyse the human cells. Each culture and wash was collected in a final volume of $2 \mathrm{~mL}$; then, $0.1 \mathrm{~mL}$ from these suspensions were plated on plates with brain-heart infusion agar medium (Difco Laboratories, Detroit, MI, USA) supplemented with $0.5 \%$ of gentamicin, $4 \%$ normal horse serum. Also, $5 \%$ of 192 water extracts from the $P$. brasiliensis strain was added as the source of growth-promoting factor (Kurita et al. 1993). As a control, a culture containing only $100 \mu \mathrm{L}$ of viable Pb18 yeast cells $\left(4 \times 10^{4}\right.$ viable units $/ \mathrm{mL}$ in complete medium) was submitted to the same procedures. Each culture had three inoculated plates triplicate, which were incubated at $35^{\circ} \mathrm{C}$ in sealed plastic bags to prevent drying. After 10 days, the number of colony-forming units

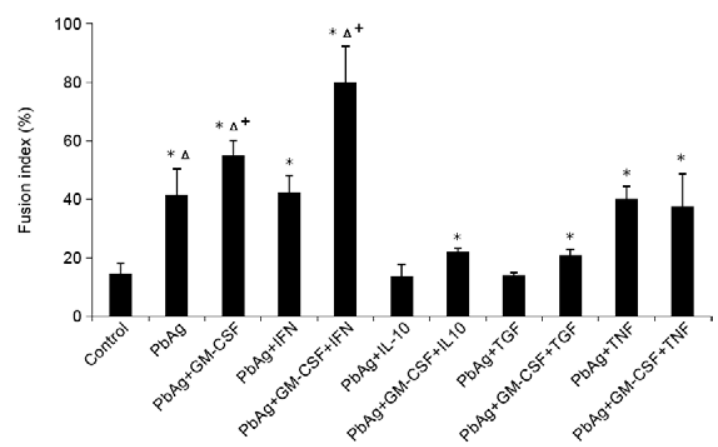

Fig. 1: the multinucleated giant cells fusion index was determined from human monocytes cultured for three days without stimulus (control), or with Paracoccidioides brasiliensis antigens $(\mathrm{PbAg})(100 \mathrm{ug} / \mathrm{mL})$, or association of $\mathrm{PbAg}$ with granulocyte macrophage colony-stimulating factor (GM-CSF) (100 IU/mL), interferon-gamma (IFN- $\gamma)(300 \mathrm{IU} /$ $\mathrm{mL})$, interleukin (IL)-10 (50 IU/mL), transforming growth factor beta $\left(\mathrm{TGF}-\beta_{1}\right)(250 \mathrm{pg} / \mathrm{mL})$ or tumour necrosis factor-alpha (TNF- $\left.\alpha\right)(50 \mathrm{IU} /$ $\mathrm{mL})$. Results are expressed as mean + standard error of the means of 20 healthy subjects. $*$ : $(\mathrm{p}<0,001)$ vs. control; $\Delta:(\mathrm{p}<0.05)$ vs. $\mathrm{PbAg}+$ IL-10, PbAg + TGF- $\beta_{1} ;+:(\mathrm{p}<0.01)$ vs. PbAg, PbAg + GM-CSF, PbAg + IFN- $\gamma$, PbAg + GM-CSF + IL-10, PbAg GM-CSF + TGF- $\beta_{1}$, PbAg + TNF- $\alpha, \mathrm{PbAg}+\mathrm{GM}-\mathrm{CSF}+\mathrm{TNF}-\alpha$ (analysis of variance).
(CFU) per plate was counted using a colony counter (Quimis, São Paulo, Brazil). The percentage of fungicidal activity was determined by the following formula: $\%$ fungicidal activity $=1-$ (mean CFU of experimental culture/mean CFU of control culture) x 100.

Statistical analysis - Data were analysed using GraphPad InStat (GraphPad Software, version 3.05, San Diego, CA, 2000). Differences in FI, MGC formation and fungicidal activity of MGC cultured with or without $\mathrm{PbAg}$ and different cytokines were compared by oneway analysis of variance followed by multiple comparisons according to the Tukey-Kramer method. Significance was determined at $\mathrm{p}<0.05$.

\section{RESULTS}

GM-CSF enhances FI in PbAg-challenged MGC The optimal concentration of the various cytokines to be employed in the assays for $\mathrm{PbAg}$-stimulated MGC formation was determined before the beginning of the experiments. Initially, the human monocytes were cultured with or without different concentrations of IFN- $\gamma$ $(50,100,300$ and 1,000 IU/mL), GM-CSF (50, 100, 200, 500 and $1,000 \mathrm{IU} / \mathrm{mL})$, TNF- $\alpha$ or IL-10 $(50,100$ and $200 \mathrm{IU} / \mathrm{mL})$, or TGF- $\beta_{1}(50,100,250$ and $500 \mathrm{pg} / \mathrm{mL})$ and either alone or in association with $\mathrm{PbAg}$. The best effect on monocyte fusion was obtained when the cells were co-cultured with cytokines and $\mathrm{PbAg}$ (Fig. 1).

The modulatory effects of IFN- $\gamma$, GM-CSF, IL-10, TGF- $\beta_{1}$ and TNF- $\alpha$ on MGC formation from monocytes stimulated with $\mathrm{PbAg}$ showed that treatment with $\mathrm{PbAg}$ only or PbAg with GM-CSF, IFN- $\gamma$ and TNF- $\alpha$ induced significantly higher FI than those observed in the nonstimulated control cultures (Fig. 2). When GM-CSF was added to the cultures stimulated with PbAg plus IFN- $\alpha$, the fusion rate was significantly higher than cultures stimulated with only $\mathrm{PbAg}$. In contrast, the addition of IL-10 or TGF- $\beta$ to the cultures stimulated with $\mathrm{PbAg}$ led to low MGC formation and had similar formation with the control cultures. The addition of GM-CSF to cultures treated with PbAg plus IL- 10 or PbAg plus TGF- $\beta_{1}$ partially inhibited the suppressive effects of these antiinflammatory cytokines on MGC formation.

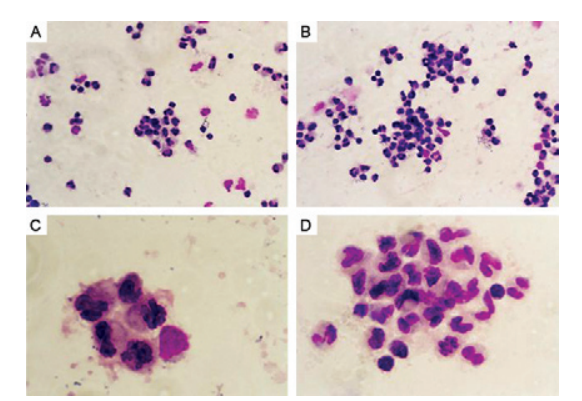

Fig. 2: typical examples of multinucleated giant cells formation after three days of monocyte cultured with Paracoccidioides brasiliensis antigens (PbAg) (A) (100 ug/mL) (200X) or PbAg (B) (100 ug/mL) in association with granulocyte macrophage colony-stimulating factor $(100 \mathrm{IU} / \mathrm{mL})(200 \mathrm{X})$. C: Langhans giant cells (400X); D: foreign body giant cells (400X). 
Formation of predominantly FBGC with cytokines - After monocyte stimulation with $\mathrm{PbAg}$ or $\mathrm{PbAg}$ plus GM-CSF, IFN- $\gamma$, IL-10, TGF- $\beta_{1}$ or TNF- $\alpha$, predominantly FBGC-like cells were formed with all the various stimuli (Table). In cultures stimulated with PbAg plus IFN- $\gamma$, there was a slight increase in the formation of LGC-like cells. Fig. 3 shows representative photomicrographs of MGC formation, FBGC-like and LGC-like cells.

GM-CSF upregulates fungicidal activity of MGC challenged with Pb18 - Fungicidal activity of MGC against $\mathrm{Pb} 18$ induced by $\mathrm{PbAg}$ with pro or anti-inflammatory cytokines can be observed in Fig. 2. MGC generated with only $\mathrm{PbAg}$ or $\mathrm{PbAg}$ plus GM-CSF or IFN- $\gamma$ presented significantly higher fungicidal activity compared to control cultures, non-stimulated cultures or cultures treated with IL-10, TGF- $\beta_{1}$ or TNF- $\alpha$. The highest fungicidal activity of MGC was obtained after stimulation with $\mathrm{PbAg}$ plus GM-CSF and IFN- $\gamma$; the lowest fungicidal activity was detected when IL-10 was added to the culture stimulated with $\mathrm{PbAg}$. The addition of GM-CSF to cultures treated with IL-10 induced low fungicidal activity relative to the cultures stimulated with the other cytokines, but significantly higher than cultures treated only with IL-10. These results demonstrate that the inhibitory effect of IL-10 on the cultures was partially reverted by GM-CSF treatment and GM-CSF enhanced the capacity of MGC to kill the fungus.

\section{DISCUSSION}

This study demonstrated for the first time that GMCSF is the best cytokine to induce FI of monocyte derived-MGC challenged with $\mathrm{PbAg}$. Additionally, GMCSF significantly increased the fungicidal activity of MGC against $\mathrm{Pb} 18$ with the addition of IFN- $\gamma$.

The antigen employed for MGC generation induced a significant increase in monocyte fusion within $72 \mathrm{~h}$ of culture. This cell-free-antigen (CFA) contains polypeptides in the 10-110 $\mathrm{kDa}$ range. The specific antigen $43 \mathrm{kDa}$ (gp43) of $P$. brasiliensis predominates in all CFA preparations that are employed for the diagnosis of paracoccidioidomycosis (Camargo et al. 1991). As gp43 interacts with the mannose receptors in macrophages (Almeida et al. 1998, Popi et al. 2002), it is possible for the CFA to induce MGC formation by a mannose receptor-mediated mechanism previously suggested by DeFife et al. (1997). Other parasitic antigens have been employed in studies of MGC formation. The in vitro generation of MGC derived from PBMC of patients with active schistosomiasis stimulated with soluble egg antigen or adult worm antigen preparations from Schistosoma mansoni was attributed to persistent antigenic stimulation (Silva-Teixeira et al. 1993). Heat-killed Candida albicans yeast cells also induced monocyte proliferation and MGC formation within four days of culture (Heinemann et al. 1997). According to Gasser and Most (1999), direct contact of monocytes with Mycobacterim bovis, in combination with cytokines present in the supernatant cultures, is important to induce MGC formation. Additionally, membrane-bound molecules of mycobacterium and monocytes are involved in the fusion process.
TABLE

Predominance of foreign body cells (FBGC)-like formation with cytokines

\begin{tabular}{lcc}
\hline Stimuli & $\begin{array}{c}\text { LGC } \\
(\%)\end{array}$ & $\begin{array}{c}\text { FBGC } \\
(\%)\end{array}$ \\
\hline $\mathrm{PbAg}$ & $8.6+2.4^{b}$ & $91.4+6.3^{a}$ \\
$\mathrm{PbAg}+\mathrm{GM}-\mathrm{CSF}$ & $14.3+3.5^{b}$ & $85.7+4.8^{a}$ \\
$\mathrm{PbAg}+\mathrm{IFN}-\gamma$ & $20.2+3.1^{b, c}$ & $79.8+5.9^{a, d}$ \\
$\mathrm{PbAg}+\mathrm{IL}-10$ & $1.1+0.3$ & $98.9+1.2^{a}$ \\
$\mathrm{PbAg}+\mathrm{TGF}-\beta_{1}$ & $10.4+4.7^{b}$ & $89.6+6.2^{a}$ \\
$\mathrm{PbAg}+\mathrm{TNF}-\alpha$ & $14.9+3.5^{b}$ & $85.1+5.7^{a}$ \\
\hline
\end{tabular}

$a$ : $(\mathrm{p}<0.01)$ vs. Langhans giant cells $(\mathrm{LGC}) ; b:(\mathrm{p}<0.05)$ vs. Paracoccidioides brasiliensis antigens $(\mathrm{PbAg})+$ interleukin (IL)-10; $c$ : $(\mathrm{p}<0.05)$ vs. PbAg, PbAg + IL-10, PbAg + transforming growth factor beta $\left(\right.$ TGF- $\left.\beta_{1}\right) ; d$ : $(\mathrm{p}<0.05)$ vs. $\mathrm{PbAg}, \mathrm{PbAg}+$ granulocyte macrophage colony-stimulating factor (GM-CSF), PbAg + interferon-gamma (IFN- $\gamma$ ), PbAg + TGF- $\beta_{1}, \mathrm{PbAg}+$ tumour necrosis factor-alpha (TNF- $\alpha$ ). LGClike cells and FBGC-like cells were detected in cultures of human monocytes stimulated with $\mathrm{PbAg}$ or $\mathrm{PbAg}$ associated with GM-CSF (100 IU/mL), IFN- $\gamma(300 \mathrm{IU} / \mathrm{mL}), \mathrm{IL}-10$ (50 IU/ $\mathrm{mL})$, TGF- $\beta_{1}(250 \mathrm{pg} / \mathrm{mL})$ or TNF- $\alpha(50 \mathrm{IU} / \mathrm{mL})$. Results are expressed as mean + standard error of the means of 20 healthy subjects (analysis of variance).

Our PbAg-induced MGC formation results and the presence of yeast cells in granulomas of paracoccidioidomycosis suggest that these cells play an important role in the immunoregulatory mechanisms involved in granuloma formation against Pb18. Previous morphologic studies of histopathological lesions in human and experimental models of paracoccidioidomycosis found that granulomas consist of accumulated macrophages, epithelioid cells and $\mathrm{Pb} 18$ yeast cells of various sizes and sporulation inside MGC (Peraçoli et al. 1982, Montenegro \& Franco 1994, Parise-Fortes et al. 2006). These MGCs may be formed by the macrophage fusion around the fungus that secretes several antigens and can chronically stimulate these cells.

The study on the modulatory effects of cytokines on human monocytes-derived MGC formation with $\mathrm{PbAg}$ stimulation indicates that the addition of IFN- $\gamma$ or TNF- $\alpha$ to monocyte cultures stimulated with $\mathrm{PbAg}$ did not significantly enhance FI relative to cultures stimulated with only $\mathrm{PbAg}$. Anti-inflammatory cytokines IL-10 and TGF- $\beta_{1}$ had inhibitory effects on monocytes cell fusion and MGC formation in cultures stimulated with $\mathrm{PbAg}$. Our results are consistent with other publications reporting a regulatory effect of IL-10 on the MGC generation (Ikeda et al. 1998). IL-10 may also play a role in granuloma formation during infection with $M$. bovis; animals deficient in IL-10 and infected with $M$. bovis develop a more severe granulomatous response that is responsible for the microorganism elimination (Jacobs et al. 2000).

However, the fusion rate significantly increased when GM-CSF was added to monocyte cultures stimulated with $\mathrm{PbAg}$ in comparison to cultures only stimulat- 
ed with $\mathrm{PbAg}$. Other studies demonstrated that GM-CSF acts as an induction agent for MGC formation (Lee et al. 1993, Lemaire et al. 1996). Moreover, the addition of GMCSF to cultures stimulated with PbAg plus IFN- $\gamma$ led to significantly higher fusion rates than cultures stimulated with $\mathrm{PbAg}$ alone or $\mathrm{PbAg}$ plus GM-CSF or IFN- $\gamma$. These results suggest that GM-CSF has a stimulatory effect on monocyte activation that leads to increased cell fusion when stimulated with $\mathrm{PbAg}$ and IFN- $\gamma$. The highest amount of MGC formation was observed in monocyte cultures stimulated with PbAg plus GM-CSF and IFN- $\gamma$ these results suggest a synergistic effect of GM-CSF on monocyte fusion induced by IFN- $\gamma$.

Evaluation of differentiated LGC and FBGC-like cell morphology after cytokine-stimulation demonstrated that, despite a slight increase in LGC formation after $\mathrm{PbAg}$ plus IFN- $\gamma$ stimulation, there was a higher percentage of FBGC in all the cultures treated with the various combinations of cytokines. These results are contrasting to previous literature reporting a higher number of LGC with IFN- $\gamma$ stimulation. One possible explanation for these differences may be related to the incubation time for monocyte-derived MGC formation. Some authors stimulate monocytes with IFN- $\gamma$ for seven-14 days to obtain a high number of LGC (Most et al. 1990, Seitzer et al. 2001). In our study, monocytes were stimulated three days for MGC generation, similar to other authors (Gasser \& Most 1999, Anderson 2000, Zhu \& Friedland 2006). However, it is accepted that FBGC may represent LGC in early stages of formation prior to the circular arrangement of nuclei (McNally \& Anderson 1995, Mizuno et al. 2001). FBGC may mature to LGC by intracellular cytoskeleton movements as previously suggested (Adams 1976).

The fungicidal activity of monocyte-derived MGC treated with viable $\mathrm{Pb} 18$ yeast cells was also comparatively assessed. The fungicidal activity of MGC stimulated with $\mathrm{PbAg}$ plus IFN- $\gamma$ or PbAg plus IFN- $\gamma$ and GMCSF was significantly higher than the activity of MGC induced by TNF- $\alpha$, IL-10 and TGF- $\beta$. These results confirm our previous study demonstrating that IFN- $\gamma$ and $\mathrm{PbAg}$ promote $\mathrm{MGC}$ formation and also the fungicidal activity of these cells (Nascimento et al. 2008).

Although the function of MGC remains unknown, Enelow et al. (1992a) demonstrated that MGC have greater fungicidal activity against $C$. albicans than macrophages. The increased fungicidal activity of MGC was attributed, at least in part, to their enhanced oxidative activity. MGC are formed under inflammatory conditions and MGC are more responsive to cytokine exposure than macrophages (Enelow et al. 1992b). The elevated MGC fungicidal activity against $\mathrm{Pb} 18$ observed in our cultures could be explained by the enhanced activation of these cells by pro-inflammatory cytokines.

Previous studies on the fungicidal activity of human monocytes against $\mathrm{Pb} 18$ indicated that IFN- $\gamma$ plays an important role in monocyte and macrophage activation, which leads to the inhibition of fungal replication in these cells (Calvi et al. 2003). The synergistic effects of IFN- $\gamma$ and GM-CSF on MGC formation were also observed in the fungicidal activity of these cells against $\mathrm{Pb} 18$. GM-CSF is known to activate monocytes and

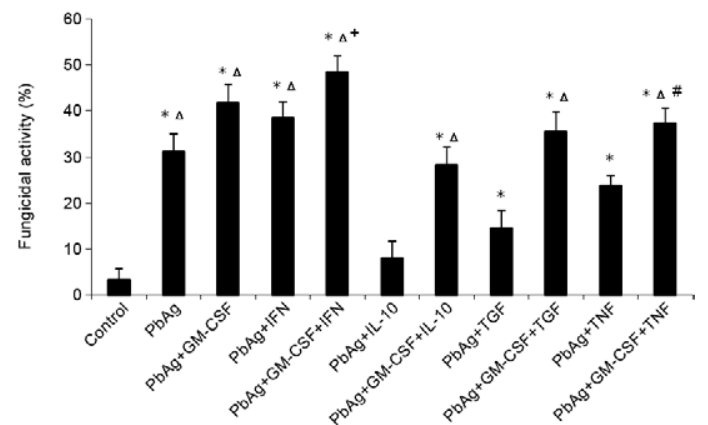

Fig. 3: fungicidal activity of multinucleated giant cells (MGC) against Paracoccidioides brasiliensis strain 18 (Pb18). Monocytes were cultured without (control) or with P. brasiliensis antigens $(\mathrm{PbAg})$ $(100 \mathrm{ug} / \mathrm{mL})$ or association of $\mathrm{PbAg}$ with granulocyte macrophage colony-stimulating factor (GM-CSF) $(100 \mathrm{UI} / \mathrm{mL})$, interferon-gamma $(\mathrm{IFN}-\gamma)(300 \mathrm{UI} / \mathrm{mL})$, interleukin (IL)-10 $(50 \mathrm{UI} / \mathrm{mL})$, transforming growth factor beta $\left(\mathrm{TGF}-\beta_{1}\right)(250 \mathrm{pg} / \mathrm{mL})$ or tumour necrosis factoralpha $(\mathrm{TNF}-\alpha)(50 \mathrm{UI} / \mathrm{mL})$ for $72 \mathrm{~h}$. After, MGC cultures were challenged with $4 \times 10^{4}$ viable $\mathrm{Pb} 18$ yeast cells for $4 \mathrm{~h}$. Results are expressed as mean + standard error of the means of 20 healthy subjects. *: $(\mathrm{p}<$ $0.01)$ vs. control; $\Delta:(\mathrm{p}<0.01)$ vs. PbAg $+\mathrm{IL}-10 ; \mathrm{PbAg}+\mathrm{TGF}-\beta_{1}$; \#: (p $<0.05)$ vs. PbAg + TNF- $\alpha$; + : $(\mathrm{p}<0.01)$ vs. PbAg, PbAg + GM-CSF, $\mathrm{PbAg}+\mathrm{IFN}-\gamma, \mathrm{PbAg}+\mathrm{GM}-\mathrm{CSF}+\mathrm{IL}-10, \mathrm{PbAg}+\mathrm{GM}-\mathrm{CSF}+\mathrm{TGF}-\beta_{1}$, $\mathrm{PbAg}+\mathrm{TNF}-\alpha, \mathrm{PbAg}+\mathrm{GM}-\mathrm{CSF}+\mathrm{TNF}-\alpha$ (analysis of variance).

promote microbicidal activity (O'Mahony et al. 2008); therefore, GM-CSF may be important to enhance fungicidal activity of MGC challenged by $\mathrm{Pb} 18$.

The treatment of PbAg-induced MGC with IL-10 and TGF- $\beta_{1}$ significantly inhibited the fungicidal activity against Pb18. These regulatory cytokines also suppress immune responses against $M$. tuberculosis by inhibiting macrophage function, thus, resulting in intracellular growth of this pathogen (Jacobs et al. 2000). However, the suppressive effects of these cytokines were attenuated and enhanced fungicidal activity was observed when GM-CSF was added to PbAg-stimulated cultures and treated with IL-10 or TGF- $\beta_{1}$. These results suggest that GM-CSF reverts the inhibitory effects of IL-10 and TGF- $\beta_{1}$ on MGC formation. Together our results show that GM-CSF plays an important role in PbAg-stimulated MGC formation and enhances the fungicidal activity of these cells. The positive effects of GM-CSF on fungicidal activity, even in the presence of anti-inflammatory cytokines, suggest a modulatory effect on MGC formation and fungicidal activity against $\mathrm{Pb} 18$.

\section{REFERENCES}

Adams DO 1976. The granulomatous inflammatory response. A review. Am J Pathol 84: 164-192.

Almeida SR, Unterkircher CS, Camargo ZP 1998. Involvement of the major glycoprotein (gp43) of Paracoccidioides brasiliensis in attachment to macrophages. Med Mycol 36: 405-411.

Anderson JM 2000. Multinucleated giant cells. Curr Opin Hematol 7: 40-47.

Belosevic M, Finbloom DS, Van Der Meide PH, Slayter MV, Nacy CA 1989. Administration of monoclonal anti-IFN- $\gamma$ antibodies in vivo abrogates natural resistance of $\mathrm{C} 3 \mathrm{H} / \mathrm{HcN}$ mice infection with Leishmania major. J Immunol 143: 266-274. 
Calvi SA, Peraçoli MTS, Mendes RP, Marcondes-Machado J, Fecchio D, Marques SA, Soares AMVC 2003. Effect of cytokines on the in vitro fungicidal activity of monocytes from paracoccidioidomycosis patients. Microb Infect 5: 107-113.

Camargo ZP, Taborda CP, Rodrigues EG, Travassos LR 1991. The use of cell-free antigens of Paracoccidioides brasiliensis in serological tests. J Med Vet Mycol 29: 31-38.

Chensue SW, Terebuh PD, Warmington KS, Hershey SD, Evanoff HL, Kunkel SL, Higashi GI 1992. Role of IL-4 and IFN- $\gamma$ in Schistosoma mansoni egg-induced hypersensitivity granuloma formation. Orchestration, relative contribution and relationship to macrophage function. J Immunol 148: 900-906.

De Brito T, Franco MF 1994. Granulomatous infection. Rev Inst Med Trop Sao Paulo 36: 185-192.

DeFife KM, Jenney CR, McNally AK, Colton E, Anderson JM 1997. Interleukin-13 induces human monocyte/macrophage fusion and macrophage mannose receptor expression. J Immunol 158: 3385-3390.

Enelow RI, Sullivan GW, Carper HT, Mandell GL 1992a. Cytokineinduced human multinucleated giant cells have enhanced candidacidal activity and oxidative capacity compared with macrophages. J Infect Dis 166: 664-668.

Enelow RI, Sullivan GW, Carper HT, Mandell GL 1992b. Induction of multinucleated giant cell formation from in vitro culture of human monocytes with interleukin-3 and interferon-gamma: comparison with other stimulatin factors. Am Rev Respir Cell Mol Biol 6: 57-62.

Fais S, Burgio VL, Silvestri M, Capobianchi MR, Pacchiarotti A, Pallone F 1994. Multinucleated giant cells generation induced by interferon- $\gamma$. Changes in the expression and distribution of the intercellular adhesion molecule-1 during macrophages fusion and multinucleated giant cell formation. Lab Invest 71: 737-744.

Franco M, Peraçoli MTS, Soares AMVC, Montenegro MR, Mendes RP, Meira DA 1993. Host-parasite relationship in paracoccidioidomycosis. Curr Top Med Mycol 5: 115-149.

Gasser A, Most J 1999. Generation of multinucleated giant cells in vitro by culture of human monocytes with Mycobacterium bovis BCG in combination with cytokine-containing supernatants. Infect Immun 67: 395-402.

Hassan NF, Kamani N, Meszaros MM, Douglas SD 1989. Induction of multinucleated giant cell formation from human blood-derived monocytes by phorbol myristate acetate in vitro culture. $J$ Immunol 143: 2179-2184.

Heinemann DE, Peters JH, Gahr M 1997. A human in vitro granuloma model using heat killed Candida albicans cells immobilized on plastic culture wells. Scand J Immunol 45: 596-604.

Helming L, Gordon S 2007. The molecular basis of macrophage fusion. Immunobiol 212: 785-793.

Iabuki K, Montenegro MR 1979. Experimental paracoccidioidomycosis in the Syrian hamster: morphology, ultrastructure and correlation of lesions with presence of specific antigens and serum level of antibody. Mycopathologia 67: 31-41.

Ikeda T, Ikeda K, Sasaki K, Kawakami K, Hatake K, Kaji Y, Norimatsu H, Harada M, Takahara J 1998. IL-13 as well as IL-4 induces monocytes/macrophages and a monoblastic cell line (UG3) to differentiate into multinucleated giant cells in the presence of M-CSF. Biochem Biophys Res Commun 253: 265-272.

Jacobs M, Brown N, Allie N, Gulert R, Ryffel B 2000. Increased resistance to mycobacterial infection in the absence of interleukin10. Immunol 100: 494-501.
Kurita N, Sano A, Coelho KIR, Takeo K, Nishimura K, Miyaji M 1993. An improved culture medium for detecting live yeast phase cells of Paracoccidioides brasiliensis. J Med Vet Mycol 31: 201-205.

Lee TT, Martin FC, Merrill JE 1993. Lymphokine induction of rat microglia multinucleated giant cell formation. Glia 8: 51-61.

Lemaire I, Yang H, Lauzon W, Gendron N 1996. M-CSF and GM-CSF promote alveolar macrophage differentiation into multinucleated giant cells with distinct phenotypes. J Leukoc Biol 60: 509-518.

Li CY, Lam KW, Yam LT 1973. Esterases in human leukocytes. J Histochem Cytochem 21: 1-12.

Lockwood DN, Lucas SB, Desikan KV, Ebenezer G, Suneetha S, Nicholls P 2008. The histological diagnosis of leprosy type 1 reactions: identification of key variables and an analysis of the process of histological diagnosis. J Clin Pathol 61: 595-600.

Lowry OH, Rosebrough NJ, Farr AL, Randal RJ 1951. Protein measurement with the Folin phenol reagent. J Biol Chem 193: 265-275.

McInnes A, Rennick DM 1988. Interleukin 4 induces cultured monocytes/macrophages to form giant multinucleated cells. $J$ Exp Med 167: 598-611.

McNally AK, Anderson JM 1995. Interleukin-4 induces foreign body giant cells from human monocytes/macrophages: differential lymphokine regulation of macrophage fusion leads to morphological variants of multinucleated giant cells. $\mathrm{Am} \mathrm{J}$ Pathol 147: 1487-1499.

Mizuno K, Okamoto H, Horio T 2001. Heightened ability of monocytes from sarcoidosis patientes to form multinucleated giant cells in vitro by supernatants of concanavalin A-stimulated monocuclear cells. Clin Exp Immunol 126: 151-156.

Montenegro MR, Franco M 1994. Pathology. In M Franco, CS Lacaz, AM Restrepo, G Del Negro (eds.), Paracoccidioidomycosis, CRC Press, Boca Raton, p. 131-150.

Most J, Neumayer HP, Dierich MP 1990. Cytocine-induced generation of multinucleated giant cells in vitro requires interferongamma and expression of LFA1. Eur J Immunol 20: 1661-1667.

Nascimento MP, Campos Soares AM, Dias-Melicio LA, PariseFortes MR, Martins RA, Nakaira ET, Peraçoli MT 2008. Fungicidal activity of human monocyte-derived multinucleated giant cells induced in vitro by Paracoccidioides brasiliensis antigen. Mycopathologia 166: 25-33.

Okamoto H, Mizuno K, Horio T 2004. Human monocyte-derived multinucleated giant cells. Nihon Hansenbyo Gakkai Zasshi 73: 245-251.

O’Mahony DS, Pham U, Iyer R, Hawn TR, Liles WC 2008. Differential constitutive and cytokine-modulated expression of human Toll-like receptors in primary neutrophils, monocytes and macrophages. Int J Med Sci 5: 1-8.

Orentas RJ, Reinlib L, Hildreth JEK 1992. Anti-class II MHC antibody induces multinucleated giant cell formation from peripheral blood monocytes. J Leuk Biol 51: 199-209.

Parise-Fortes MR, Marques SA, Soares AM, Kurokawa CS, Marques ME, Peracoli MT 2006. Cytokines released from blood monocytes and expressed in mucocutaneous lesions of patients with paracoccidioidomycosis evaluated before and during trimethoprim-sulfamethoxazole treatment. $\mathrm{Br} J$ Dermatol 154: $643-650$.

Peraçoli MTS, Mota NGS, Montenegro MR 1982. Experimental paracoccidioidomycosis in the Syrian hamster: morphology and correlation of lesions with humoral and cell-mediated immunity. Mycopathologia 79: 7-17. 
Popi AF, Lopes JD, Mariano M 2002. Gp43 from Paracoccidioides brasiliensis inhibits macrophage functions. An evasion mechanism of the fungus. Cell Immunol 218: 87-94.

Puissegur MP, Lay G, Gilleron M, Botella L, Nigou J, Marrakchi H, Mari B, Duteyrat JL, Guerardel Y, Kremer L, Barbry P, Puzo G, Altare F 2007. Mycobacterial lipomannan induces granuloma macrophage fusion via a TLR2-dependent, ADAM9- and beta1 integrin-mediated pathway. J Immunol 178: 3161-3169.

Seitzer U, Haas H, Gerdes J 2001. A human in vitro granuloma model for the investigation of multinucleated giant cell and granuloma formation. Histo Histopathol 16: 645-653.

Silva-Teixeira DN, Ferreira MG, Nogueira-Machado JA, Doughty BL, Goes AM 1993. Human giant cell formation induced in vitro by Schistosoma mansoni antigens. Brazilian J Med Biol Res 26: 609-613.
Soares AM, Calvi SA, Peraçoli MT Fernandez AC, Dias LA, Dos Anjos AR 2001. Modulatory effect of prostaglandins on human monocyte activation for killing of high and low-virulence strains of Paracoccidioides brasiliensis. Immunol 102: 480-485.

Tambuyzer BR, Nouwen EJ 2005. Inhibition of microglia multinucleated giant cell formation and induction of differentiation by GMCSF using a porcine in vitro model. Cytokine 31: 270-279.

Wanke B, Londero AT 1994. Epidemiology and paracoccidioidomycosis infection. In M Franco, CS Lacaz, A Restrepo-Moreno, G Del Negro (eds.), Paracoccidioidomycosis, CRC Press, Boca Raton, p. 109-120.

Zhu XW, Friedland JS 2006. Multinucleate giant cells and the control of chemokine secretion in response to Mycobacterium tuberculosis. Clin Immunol 120: 10-20. 